Article

\title{
Conditions for Successfully Increasing Disadvantaged Adolescents' Engagement in and Development through Volunteering in Community Sport
}

\author{
Evi Buelens ${ }^{1, *}$, Marc Theeboom ${ }^{1}$, Jikkemien Vertonghen ${ }^{1}$ and Kristine De Martelaer ${ }^{2,3}$ \\ ${ }^{1}$ Research group Sport \& Society, Vrije Universiteit Brussel, 1050 Brussels, Belgium; E-Mails: evi.buelens@vub.be (E.B.), \\ marc.theeboom@vub.be (M.T.), jikkemien.vertonghen@vub.be (J.V.) \\ ${ }^{2}$ Research Group of Motor Skills and Didactics, Vrije Universiteit Brussel, 1050 Brussels, Belgium; \\ E-Mail: kdmartel@vub.be \\ ${ }^{3}$ Division of Education, Faculty of Social and Behavioral Sciences, Utrecht University, 3512 JE Utrecht, The Netherlands \\ * Corresponding author
}

Submitted: 31 January 2017 | Accepted: 20 April 2017 | Published: 29 June 2017

\begin{abstract}
A considerable number of adolescents in Western societies live in socially vulnerable situations. Approaches to improve this situation ultimately aim to make institutional changes through a focus on individual development. With regard to the latter, there have been high expectations regarding sport volunteering's contribution to human capital development. Nevertheless, little understanding of the underlying conditions for, and possible outcomes of sport volunteering exists. This study's aim was twofold: (1) to assess the conditions necessary to develop the human capital of disadvantaged adolescents through volunteering in community sport, and (2) to assess to what extent human capital can be developed. A qualitative research design was used to attain deeper insight into these conditions within eight community sport programs in Flanders (Northern Dutch-speaking region of Belgium), a setting that is not often used for youth developmental practices. Data were collected on repeated occasions over the course of each program through qualitative methods with local sport services and social partner organizations $(N=26)$ and participating adolescents $(N=26)$. Inductive analysis identified two categories of necessary conditions, (1) valuing and recognizing adolescents, and (2) informal and experiential learning. Results further showed the achievement of two types of perceived human capital developmental outcome (i.e., personal and interpersonal competences) through the fulfilment of these conditions. Findings also showed that although two of these programs made use of a more critical pedagogical approach to youth development by encouraging participants, not only to reflect on, but also to critically take part in the transformation of their own position within society; critical youth empowerment was not reached in the majority of the programs.
\end{abstract}

\section{Keywords}

community sport; disadvantaged adolescents; human capital; volunteering

Issue

This article is part of the issue "Sport for Social Inclusion: Questioning Policy, Practice and Research", edited by Reinhard Haudenhuyse (Vrije Universiteit Brussel, Belgium).

(C) 2017 by the authors; licensee Cogitatio (Lisbon, Portugal). This article is licensed under a Creative Commons Attribution 4.0 International License (CC BY).

\section{Introduction}

\subsection{Disadvantaged Adolescents}

$15.4 \%$ of adolescents in the European Union (EU) between the age of 15 and 29 years, live in a problematic situation (Eurofound, 2012) often characterized by a lack of engagement with any form of employment, education or training (i.e., NEET), resulting in higher chances to live or risk ending up living in socially vulnerable situations. Different disadvantages are emphasized by the EU, both on individual (e.g., social exclusion, poor men- 
tal and physical education) as well as on societal and economical levels (Eurofound, 2012). Besides, research has stressed that non- and low-educated adolescents have fewer chances in the labor market and higher chances of ending up in poverty (Dierckx, Coene, Van Haarlem, \& Raeymaekers, 2013; Sourbron \& Herremans, 2013). In more general terms, this group of adolescents has been labeled, amongst other things, as being underserved, at-risk, disadvantaged, marginalized or deprived, which frequently emphasizes the individual causes of their problematic situation (Haudenhuyse, Theeboom, \& Coalter, 2012).

To improve adolescents' vulnerable situations, two strategies have been emphasized. The first strategy relates to causes at the individual level, and therefore assumes adolescents should be changed, rather than the environments in which they live (Ginwright \& Cammarota, 2002). Examples are the deficit perspective (i.e., problem-driven approach, reduction in negative behaviors of 'at-risk youths') by Damon (2004) or the positive youth development approach (i.e., assets-driven approach, investment in youths' capabilities) by Benson (2006) and Lerner et al. (2005). However, researchers have also attributed societal structures as reproducers and maintainers of these social inequalities (Ginwright \& Cammarota, 2002; Hartmann \& Kwauk, 2011). Vettenburg (1998) recognizes that the ideas and conceptualizations which underpin these societal structures and social arrangements are the sources of exclusionary and discriminatory processes. Her social vulnerability theory (1998), heavily drawing on Hirschi's (2009) social bonding theory and Bandura's (1977) social cognitive theory, states that the situation of these adolescents is characterized by distorted and disconnected relations with society's institutions (e.g., education, labour market, unemployment service, health care). By its very nature, social vulnerability is about interactional processes, the progressive accumulation of negative experiences among adolescents within these institutions and the lower level of benefits which those institutions provide for the target group relative to their less vulnerable counterparts. (Haudenhuyse, Theeboom, Nols, \& Coussée, 2013b; Vettenburg, 1998). Consequently, apart from an approach at the individual level to counter adolescents' socially vulnerable situations, there is a need for another strategy that primarily relates to working towards structural changes at institutional levels (Coakley, 2011; Hartmann \& Kwauk, 2011; Haudenhuyse et al., 2012; Haudenhuyse, Theeboom, \& Nols, 2013a; Kelly, 2011; Vettenburg, 1998). This involves, for example, rebuilding strong community-based social institutions, and re-establishing the resource base of young peoples' communities (Coakley, 2011). It also relates to increasing access to socioeconomic resources, such as family income, education and employment, housing quality and neighbourhood status (Haudenhuyse et al., 2013a). In this respect, some researchers argue that development at the individual level might cause changes at the institutional level (Gin- wright \& Cammarota, 2002; Hartmann \& Kwauk, 2011). According to Hartmann and Kwauk (2011), adolescents therefore need to be empowered to critically take part in the transformation of not only their own experiences of society, but also of society itself. As a consequence, different researchers argue for the investment in the human capital of socially vulnerable adolescents.

\subsection{Human Capital}

Human capital is a concept that long has been viewed as the knowledge, skills, and capacities of an individual to perform in the labour market (Becker, 1964). Therefore, the concept has been mainly regarded within the human resources management and economic literature and has been often presented as school and labour market competences (Schultz, 1961). In recent years, however, an increasing number of researchers are viewing this topic with a wider perspective and are focusing on a broader notion of human capital (Krauss, Hamzah, Suandi, \& Tamam, 2007). This shift is also reflected in the evolution of the definition used by the OECD towards 'the knowledge, skills, competences and attributes embodied in individuals that facilitate the creation of personal, social and economic well-being. Besides specific cognitive skills and explicit knowledge, a broader notion of human capital also encompasses non-cognitive skills and attributes which contribute to the well-being of a person (OECD, 2001, p. 18). However, due to different exclusionary mechanisms, through common strategies such as formal education and on-the-job-training, disadvantaged adolescents can invest in their human capital, albeit to a lesser extent than their less vulnerable counterparts (Bynner, 2005; Spaaij, 2009; Vettenburg, $1998,2011)$. Consequently, different programs are organized in leisure settings, aimed at vulnerable adolescents' development (Coalter, 2012; Gambone \& Arbreton, 1997; Witt \& Crompton, 1997) since they are believed to provide opportunities to develop adolescents' human capital (Glover \& Hemingway, 2005). Interventions mostly focus on the development of competences and the provision of learning experiences by attempting to increase adolescents' sense of responsibility and involvement (Dworkin, Larson, \& Hansen, 2003; McLaughlin, 2000; Roth, Brooks-Gunn, Murray, \& Foster, 1998). Additionally, Dworkin and colleagues (2003) suggested that, at least at the high school age, leaders' focus might be better directed, not at teaching adolescents, but at helping them to teach themselves, since adolescents reported to see themselves as agents of their own human capital development.

\subsection{Role of Volunteering in Sport}

Literature reports that investment in human capital can be fostered by putting adolescents in situations where they can learn and take up responsibilities (Kay \& Bradbury, 2009). In this respect, volunteering has been men- 
tioned as a method by which people can invest in their own human capital by acquiring organizational, leadership, speaking and writing skills (Day \& Devlin, 1998; Smith, 2010). According to Wilson (2000, p. 125) 'volunteering means any activity in which time is given freely to benefit another person, group, or organization. This does not preclude volunteers from benefiting from their work'. Hogan and Owen (2000), furthermore, indicated that volunteering is discursively positioned as a key form of active citizenship since public service sector provision is progressively being replaced by a greater role for volunteers. In addition, according to Risler and Holosko (2009), volunteering can also contribute to the development of empowerment. The multi-level construct of empowerment is consistent with experiential learning (Kolb, 1984) and is described by many authors (e.g., Rappaport, 1987; Van Regenmortel, 2002, 2009; Zimmerman, 2000). According to Van Regenmortel $(2002,2009)$, empowerment looks from an insider's perspective, at amongst other things, the fact that an individual can also learn from their own experiences. Although this focuses on the individual level (and therefore seems to imply personal causes of vulnerability), critical youth empowerment however, emphasises the potential of individuals to strengthen their ability to understand the broader power structures within which they are contained (Jennings, Parra-Medina, Hilfinger-Messias, \& McLoughlin, 2006). According to Jennings and Green (1999), the aim of critical youth empowerment is to support and foster adolescents' contributions to positive community development and socio-political change, resulting in adolescents who are critical citizens, actively participating in the day-to-day building of stronger, more equitable communities. In this respect, Jennings and colleagues (2006) described six key dimensions of critical youth empowerment: (1) a welcoming, safe environment, (2) meaningful participation and engagement, (3) equitable power-sharing between youths and adults, (4) engagement in critical reflection on interpersonal and sociopolitical processes, (5) participation in socio-political processes to affect change, and (6) integrated individual and community-level empowerment.

Sport, as one of the most popular leisure pastimes among adolescents (Vanhoutte, 2007), is thereby seen as an interesting setting to offer possibilities for volunteering (Kay \& Bradbury, 2009). It is believed that sport can provide rich contexts for reaching out to disadvantaged adolescents (Crabbé, 2006; Haudenhuyse et al., 2012, 2013a; Hellison \& Walsh, 2002; Spaaij, 2009) as well as developmental opportunities for this group, such as personal and social competences and community building (Coalter, 2007; Hartmann \& Kwauk, 2011). Haudenhuyse and Theeboom (2012) even argued that in the context of the social vulnerability theory, sport is viewed as a tool to alleviate the distorted relationships of adolescents, and alleviate the believed outcomes (i.e., human capital) they produce. However, in order for sport and volunteering to be used as developmental opportunities for this group, there is an issue of accessibility. In addition to their low level of involvement in organized sports in general (Haudenhuyse et al., 2013a), there is also an underrepresentation of the target group among volunteers in sport and youth sports volunteering training programs (Eley \& Kirk, 2002; Kay \& Bradbury, 2009). In fact, this is hardly surprising given that education, income and social networks are considered to be the most consistent predictors of volunteering (e.g., Koning Boudewijnstichting, 2015; Penner, 2002; Taylor, Panagoulas, \& Nichols, 2012; Wilson, 2000). Consequently, this has resulted in the provision of alternative formats to reach out to disadvantaged adolescents. It is interesting that most of these alternatives were initially provided by 'non-sport' actors including community centres, youth welfare work, and social organizations (Theeboom, Haudenhuyse, \& De Knop, 2010). It is only in more recent times that the sport sector has become more involved as well (mostly through community sport organizations aimed at reaching and engaging the 'hard to reach').

\subsection{Community Sport}

As indicated by Hylton and Totten (2008), the concept of community sports originally arose out of the realization that traditional participation patterns were dominated by advantaged sections of the population and therefore an alternative approach was needed. For example, in Flanders, Belgium's northern Dutch speaking region, like in other Western European countries, specific community sport initiatives have been set up by local governments to better reach the 'hard to reach' (Marlier, Cardon, De Bourdeaudhuij, \& Willem, 2014; Theeboom \& De Maesschalck, 2006). It mainly consists of (low threshold) sport initiatives and programs set up through partnerships between various local actors, such as local (municipal) sport services, welfare organizations, schools and-to a lesser extent-sport clubs (Theeboom et al., 2010). Community sport provision is described as an approach characterized by: (1) being demand-driven and adjusted according to the specific target group's needs, (2) having structural collaboration between various actors, (3) the use of a variety of organizational formats, (4) emphasis on a broader sport notion, and (5) the use of infrastructural facilities in a creative way (Theeboom et al., 2010). Pouw and Daniels (2001) made a distinction between three models of community sport in The Netherlands: (1) 'participation', with sport being a goal for the whole population in a specific neighbourhood, (2) 'target group', where sport is regarded both as a goal and a means and aimed at a variety of specific groups, and (3) 'integral', characterized solely as being instances where sport is a means for socially deprived groups in specific neighbourhoods. As we will focus on developmental opportunities for adolescents in socially vulnerable situations, community sport will be regarded from an 'integral' model perspective for the remainder of this article, as it is the model adopted by the organizations which were investigated. 


\subsection{High Expectations, Limited Insights}

It is interesting to note that, while there is a growing number of community sport programs that focus on the developmental potential of sport for adolescents in socially vulnerable situations, at the same time, there is an increase in the number of researchers who question this potential (e.g., Coakley, 2011; Coalter, 2007; Darnell, 2007, 2010; Guest, 2009; Kidd, 2008; Levermore, 2008). Firstly, according to Hartmann and Kwauk (2011), sport for development initiatives all too frequently rely on a dominant developmental vision, which they criticize. They labelled this vision as reproductive because sport essentially reproduces established social relations. It is used to develop socially vulnerable adolescents to satisfy prevailing standards and to become 'acceptable' to a mainstream society. Coalter (2013) furthermore, argued that most of these programs regard disadvantaged adolescents as 'deficient' and therefore in need of an intervention. As a result, some have called for an alternative and more critical approach to sport-based youth developmental programs (Darnell, 2010). Scholars have labelled these critical approaches to youth development for example as 'interventionist' (Hartmann \& Kwauk, 2011), 'social justice youth development' (Ginwright \& Cammarota, 2002; Iwasaki, 2015) or 'critical youth empowerment' (Jennings et al., 2006) thereby heavily relying on Freire's (1993) 'praxis' - the reflection and action upon the world in order to transform it (1993). Secondly, different researchers question the high 'developmental' expectations that are attributed to sport engagement and the lack of a critical perspective on sport's actual value (Giulianotti, 2004). With regard to Vettenburg's social vulnerability theory (1998), sport is believed to have the potential to positively influence the cultural "hardto-measure' factors that are associated with young people's social vulnerabilities (Haudenhuyse, Theeboom, \& Skille, 2014). Hartmann and Kwauk (2011) however, indicated that there is limited empirical evidence for several positive functions of sport and sport for development programs. In this respect, Coalter (2011) pointed to the lack of monitoring and evaluation work on specific sport for development practices and to the lack of clear objectives. He specifically argued that program organizers often lack clearly formulated objectives about how sport interventions can contribute to achieving certain outcomes and the mechanisms through which these outcomes can be attained. By referring to Patricksson (1995), Coalter (2007) thereby argued that insight is lacking in two types of conditions. The first type, 'necessary conditions', refers to those conditions that need to be fulfilled in order to reach and attract disadvantaged adolescents. Coakley (2011) however, stated that 'by itself, the act of sport participation among young people leads to no regularly identifiable development outcomes' (p. 309). Therefore, a second type (i.e., 'sufficient conditions') needs to be fulfilled as well. Sufficient conditions refers to the nature of processes and the various organizational and pro- gram components that lead to the achievement of desired outcomes (Coalter, 2001).

\subsection{Study}

In recent years, while addressing the second challenge, a limited number of studies have tried to gain a deeper insight into the sufficient conditions of sport for development programs for disadvantaged adolescents (Coalter, 2012; Gould \& Carson, 2008; Sandford, Armour, \& Warmington, 2006; Spaaij, 2012). For example, Draper and Coalter (2016) stated that one of the critical success factors relates to the quality of social relationships developed during a program. Other research has also stressed the importance of social relationships (Catalano, Berglund, Ryan, Lonczak, \& Hawkins, 2004; Gambone \& Arbreton, 1997; Lerner et al., 2005; Strachan, Côté, \& Deakin, 2011). Draper and Coalter (2016) however, also referred to the need for greater clarity regarding the conditions through which sport can contribute to personal development, as well as the context in which this development is likely to take place, and with whom it would occur. It is noteworthy that, to date, most of the existing studies have looked at specific programs provided by 'non-sport' actors (e.g., community centres, youth welfare work, social and humanitarian organizations). There is, however, to date, limited insight into programs that are initiated in more 'traditional' sport structures (i.e., municipal community sport services and traditional sport clubs) and specifically aimed at increasing the engagement of disadvantaged adolescents. Greater insight is needed since Theeboom and colleagues (2010) indicated that, in more recent years, the traditional sport sector has increased contact with children and adolescents living in socially vulnerable situations (mostly through community sport organizations supported by local authorities). Within this respect, insight is needed firstly on the conditions needed to engage adolescents in vulnerable situations in sport volunteering, and secondly, on the degree to which human capital may be developed by this engagement (Kay \& Bradbury, 2009). There is, to date, limited empirical evidence indicating a direct causal relationship between volunteering in sport and human capital development or any other beneficial social outcome for adolescents in vulnerable situations. Therefore, the purpose of the present study was to: study (1) the sufficient conditions to reach development in human capital of disadvantaged adolescents through volunteering in community sport, and (2) achieved human capital developmental outcomes.

\section{Method}

Consequently, in this study, eight different community sport programs in different Flemish cities and municipalities were investigated. These were all part of the 'Street Action' project. This project was included in the study based on (1) its specific aim to empower and 
develop disadvantaged adolescents through volunteering in a community sport setting, and (2) the possibility to include a wide variety of practices in the study (i.e., large versus small cities, experienced versus inexperienced, different approaches). Within the investigated practices, volunteering concerned predominantly organizational tasks, and guidance and/or coaching of young children. The Street Action project was organized by the umbrella organization of Flemish local sport services (ISB vzw) and financed by the Coca-Cola Foundation (between 2012-2014). The main funding came from a private commercial partner, making it unique in Flanders. $\mathrm{A}$ funding prerequisite for each individual program was the coordination by the municipal community sport service and the collaboration with one or more social partners (e.g., youth welfare work, social or youth service). As a result, the organizers of each program included both a sport and social partner organization. The aims of Street Action were to increase the sport participation of disadvantaged adolescents and promote sustainable volunteering in sport among 12 to 18 -year-olds in disadvantaged situations. 'Ownership' could be seen as one of the main themes. For this, adolescents were encouraged to become regularly involved in the organization of the community sport offered in their own neighbourhood in order to 'become empowered'. The study analysed the first eight 'pilot' programs (2012-onward) which allowed ISB to get more insight into critical success factors to be taken into account during the second phase of Street Action, which included another 15 municipalities (2013-onward).

A qualitative research design was used to collect data among program organizers and participants on three occasions during the course of each program. Similar to other researchers who investigated the experiences of socially vulnerable adolescents and sport interventions (Haudenhuyse et al., 2012), an interpretative phenomenological approach (IPA) was used. IPA is an approach to qualitative analysis with the aim to explore in detail how participants make sense of their personal and social world (Smith \& Osborn, 2008). IPA is concerned with trying to understand lived experience and with how participants themselves make sense of their experiences. This approach allowed us to analyze and understand the data from the perspectives and experiences of both disadvantaged adolescents and organizers, relating to the shared phenomenon of organizing and volunteering in community sport (i.e., Street Action programs). This in order to explore their lived experiences of how they make sense and value these and how they make sense of the underlying conditions. IPA requires the researchers to collect detailed, reflective, first-person accounts from research participants. Most typically, this is in the form of a semi-structured, one-to-one interview (Smith, Flowers, \& Larkin, 2009). Other forms of data that can sometimes be used for IPA include written accounts (Smith, 1996), focus groups (Palmer, 2010), and observations (Smith et al., 2009). In the present study, data triangulation occurred by including semi-structured in-depth interviews with open questions, focus groups, and observations. An interview schedule was developed consisting of different kinds of questions (with reference to Smith et al., 2009). With regard to the focus group, these question types included, amongst others: descriptive (e.g., 'what do you do as a volunteer here'); narrative (e.g., 'can you tell me about how you came to volunteer here/why you still volunteer?'); evaluative (e.g., 'how do you feel when you are volunteering?' Do you have the feeling that volunteering is good/bad for you?); circular (e.g., 'how do you think your peers think about how you function as a volunteer?'); comparative (e.g., 'how do you think about what you would be doing in life when you were not volunteering?'); prompts (e.g., 'can you tell me a bit more what you mean by that?'); probes (e.g., 'what do you mean by that?'). Central to the interviews was a focus on the dialogue between interviewer and interviewee. In practice, probing allowed the interviewer to ask follow-up questions in order to obtain more and deeper information (e.g., why? How? What do you mean by that? Can you tell me more about that? Can you tell me what you were thinking? How did you feel?). In addition, during this data-gathering process, the interviewer avoided posing over-emphatic, manipulative and leading questions. In further interviews, participants were also involved with preliminary findings concerning the previous interviews. Observations and document analysis (plan of action, yearly reports, objectives, expectations) were executed to help contextualize the interview data in order to understand and analyze the context where the authors were gathering data within the right perspective and to compare the spoken and written with approximations in practice. Both adolescents and professionals were observed during their functioning as (and mentoring of) volunteers. Finally, a round table discussion was organized with sport partners of the programs to reflect upon our findings. In total, in the eight pilot programs 26 organizers were interviewed via 53 interviews (i.e., individuals were interviewed more than once and sometimes two or more organizers in each occasion in each program were interviewed). The interviews lasted between 35 and 70 minutes. Data collection among participants was through four focus groups (two groups of participating adolescents and two groups of organizing adolescents). In sum, 26 adolescents ( $M=13.8$, $S D=2.14)$, were involved. Smithson (2000) indicated that focus groups can be especially useful for discussing views of disadvantaged or minority groups. The interviews and focus groups were both conducted by the first author, in a familiar, safe and reasonably quiet room, chosen by the interviewees.

Data-analysis was performed in distinct different stages. First, all interviews were tape-recorded and, following a verbatim transcription, analysed inductively afterwards. Second, the first author immersed herself in the original data by reading and re-reading the first written transcripts several times, starting immediately after 
the transcription of the interview. While reading the text, she attempted to suspend presuppositions and judgments in order to focus on what was actually present in the transcript data (Larkin \& Thompson, 2012). This involved the practice of 'bracketing' (Husserl, 1970), namely the suspense of critical judgement and a temporary refusal of critical engagement which could bring in the researcher's own assumptions and experience (Larkin \& Thompson, 2012). Third, in order to develop an organized, detailed, plausible and transparent account of the meaning of the data, themes, (i.e., 'patterns of meaning in the data') were identified. These were drawn from a detailed, line-by-line analysis of the data, namely 'codes' or segments of text that were comprehensible by themselves, that contained one specific idea, episode, or piece of information (Tesch, 1990), thereby emphasizing convergence and divergence, commonality and nuance (Smith et al., 2009). Based on this open coding, general domains of the sufficient conditions for, and perceived outcomes of organizing and volunteering in community sport were identified. The initial coding was discussed with the second author and codes with a similar meaning were then grouped together leading to two main categories of sufficient conditions and two main types of perceived human capital developmental outcomes. This dialogue between researchers, the coded data and their knowledge about what it might mean for participants to have these concerns in this context, according to Smith et al. (2009), lead, in turn, to the development of a more interpretative account. A computer software program, Nvivo 10, was used to assist with the coding and sorting of the data. Fourth, the relationships between the different themes were incorporated within a structure and organized in a format which allowed coded data to be traced right through the analysis - from the initial codes on the transcript, through initial clustering and thematic development, to the final structure of themes. Researchers attempted to provide an overall structure to the analysis by relating the identified themes into 'clusters' or concepts. We arrived at a group of themes and to identify super-ordinate categories that suggest a hierarchical relationship between them. These super-ordinate categories were needed to be able to offer a framework for addressing the research aims from the perspective and experience of the interviewees (Haudenhuyse et al., 2013a). The coherence and plausibility of the interpretation were strengthened by discussion with the third author. Fifth, after reading and developing a scheme applied to the first transcript, we used this list of themes obtained from the first interviews to identify further instances of these themes in subsequent interviews. At the same time, we were also alert to the possibility of new themes which, in the event of their appearance, were tested against earlier data. With regard to the analysis of the focus groups we incorporated the advice of Smith (2004, pp. 50-51), who conducting focus groups within an IPA perspective, to 'parse' transcripts at least twice; once for group patterns and dynamics, and subsequently, for ideographic accounts. It was important that participants were able to discuss their own personal experiences in sufficient detail.

\section{Results}

\subsection{Necessary Conditions}

As already stated, the purpose of the present study was: (1) to gain insight into the sufficient conditions (i.e., the nature of processes and the various organizational and program components that lead to the achievement of desired outcomes; Coalter, 2001) needed to achieve human capital development of disadvantaged adolescents through volunteering in community sport, and (2) to assess to what extent human capital can be developed. Since it has been indicated that reaching and retaining disadvantaged adolescents constitutes the first condition for working with them towards broader developmental and societal outcomes, it is worthwhile to concentre on this aspect first. The analysis showed that, despite its aim and the high expectations towards reaching the 'hard to reach', not all community sport programs succeeded in attracting adolescents, let alone to attracting them to become involved as volunteers. One program stopped after one year because of limited or non-participation of adolescents. To some extent, five other programs were able to attract and retain disadvantaged adolescents as engaged sport participants. However, those adolescents that they were able to attract, could not be encouraged to take up volunteering. Most of the programs experienced similar difficulties. Results showed these community sport programs struggled with different necessary conditions. More specifically these related, amongst others, to (1) setting up a top-down program without prior involvement of the target group, (2) lacking clearly defined goals of the program, (3) limited knowledge of the target group and how to address them. Other necessary conditions related to (1) difficulties in lowering thresholds, (2) difficulties in informing parents, (3) absence of role models, (4) low involvement of coaches, (5) programs not being part of an integral and coordinated policy strategy, (6) no extended length of programs, sustainability clubs, (7) professional support: resolving organizational or structural difficulties and, as a result, no time to focus on social aims. Noteworthy in this respect is that the remainder of the present article will primarily describe the findings of two of the programs that were able to achieve this volunteer engagement from adolescents. Although we will mainly focus on these two 'successful' programs, we will also report on some of the findings of the unsuccessful ones. As pointed out by Coalter (2007), there is often a reluctance to publish negative results of social interventions. However, learning from failure can also provide useful insights. For example, it turned out that the main reason why these programs were not able to go beyond these above described necessary conditions (i.e., to attract and 
retain adolescents as mere participants), was simply because they did not fully recognize that they are distinct from sufficient conditions, which are needed to provide developmental opportunities through volunteering.

We will now turn to the most important findings with regard to the sufficient conditions for, and human capital developmental outcomes of, sport volunteering. Researchers' analysis resulted in two categories of sufficient conditions needed for sport volunteering: (1) valuing and recognizing adolescents, and (2) informal and experiential learning, as well as two types of perceived human capital outcomes: (1) personal, and (2) interpersonal competences. Results are presented thematically, below, and are occasionally illustrated using raw data (i.e., quotes).

\subsection{Valuing and Recognizing Adolescents}

This first category included the following four aspects: (a) bottom-up approach, (b) personal involvement, (c) reinforcing environment, and (d) official recognition. These aspects are explained in the following paragraphs.

\subsubsection{Bottom Up Approach}

According to the organizers of the two good practices, it is important to involve adolescents from the start and to let them have a say in the design and organization of the program. This resulted in an increased motivation and interest among the participating adolescents. One of these practices started with a top down approach, but changed along the way as they experienced it was not effective. A street worker described this:

The local sport service, community sport service, youth service and culture service, until now it is still a top-down programming and that's making some things really difficult. They ask me to encourage my adolescents to take part in their activities. But this is not working if the program is not tailored to the needs of the adolescents themselves.

According to the adolescents, developing a bond of trust between themselves, as well as between them and providers was considered as an important bottomup condition to get them involved. An important sufficient condition in this respect is that disadvantaged adolescents should experience appreciation simply for who they are and what they want. A prevention worker emphasized the importance for those adolescents to experience that their needs are being heard and are taken seriously. Another prevention worker (1) recounted, "The contribution of the adolescents is very important, if they don't stand behind it, then it doesn't work. So, put the adolescents central and don't force them with things they don't want".

This can be illustrated by the experiences in another Street Action program which started with a top down approach, assuming that adolescents would already be interested in taking up responsibilities and volunteering. Although several adolescents started the program, none of them were actually intrinsically motivated. Rather than taking part because of their personal interest and motivation, they merely wanted to please the youth worker. As a result, the adolescents left soon and the whole program was canceled.

\subsubsection{Personal Involvement}

Findings also showed the importance of allowing adolescents to help to fulfill their own needs. Program providers pointed out the importance of offering opportunities where adolescents can help to change things by themselves, such as by taking responsibilities as a volunteer, by being a coach or animator, or by organizing activities for children and their peers. One of the street workers stated:

You see, some adolescents, they never participated in a youth movement or the like, but still, their leadership skills appear. And for instance at school, for some adolescents, things are getting worse, while here you see them giving structure to little children. Then it surprises you a bit that they have all these skills because of your own prejudices you sometimes have with regard to these adolescents.

Another street worker added that for different participants the program facilitated their intrinsic motivation for participating in an animator course in order to take up responsibilities.

The strength of this program? That's already tangible at this moment [start of the program]. Five adolescents already said to me loud and clear that they want to participate in an animator course as soon as possible. That's incredible. That's the first time that those adolescents are willing to take up responsibilities in one of our activities.

A related condition to this is the creation of a setting where contributions and actions of the adolescents as volunteers can change things in their own neighbourhoods in order to make them feel like they are making meaningful contributions to society in general and their own neighbourhoods in particular (e.g., organization of (sport) activities in their own neighbourhoods for other disadvantaged children and adolescents).

\subsubsection{Reinforcing Environment}

Experiencing appreciation and recognition from peers, children, parents and other people within the neighborhood is regarded as another important sufficient condition. Adolescent $Y$ stated: 
My parents are favorable to the fact that I volunteer. In our family, we also have an autistic person and since I am an animator and have a certificate I work more with him and babysit on him.

It is always nice to start with your friends, but, like now, we also got to know other people. For example, without knowing it, there were other animators and we were standing together on the square. Suddenly we had a bond and they told us we were sociable..... Immediately we had a bond.

Furthermore, this relates to the acquisition of, and experiencing of having, standing in the neighborhood.

When you walk in the neighborhood you see the little children pointing at you and telling their moms 'look, that is someone from the playground' and that is always nice. (Adolescent $\mathrm{Y}$ )

According to the adolescents, positive reinforcement is an important condition for a learning environment. Results further showed that being recognized by others in their environment also related to adolescents' sense of belonging to a group. This was encouraged in the programs by providing opportunities for positive interdependence between the participating adolescents. For example, the programs in both municipalities were designed in such a way that when a participant would step out, the program had to stop. Through creating cooperative learning situations (Grineski, 1996), the active involvement of all participants was therefore essential. Adolescents needed each other in order to learn and reach their goals because each of them was given specific responsibilities. In this respect, adolescents were encouraged to make a positive choice (i.e., adherence to the program in order that all adolescents could finish the trajectory). This situation allowed adolescents to experience the feeling of being important, which in turn had a positive influence on their sustained engagement. Adolescent B stated:

That was one of the advantages, because we were all friends and if one of us decided to stop, the whole trajectory would stop. So, even though you considered about stopping, nobody would actually do because you knew stopping means that everybody has to stop.

\subsubsection{Official Recognition}

Social partners also underlined the importance of rewarding participating adolescents with an official certificate of their competence development through volunteering. For example, 'animator in youth work'. According to the youth work organization, official recognition is very important for adolescents in vulnerable situations as recognition at school is lacking for most of them. The relevance was also stressed by organizing a developmental trajectory within official institutions, such as munic- ipal (youth or sport) services. It allows adolescents to get in touch in a positive way with these structures. According to the program organizers and adolescents, this is often lacking in other contexts (e.g., school, community). Adolescent B corroborated this finding by explaining the reason he started the program: "Why I started this course? It holds many advantages and it is a way to spend my spare time. Now I can finally do things in the municipality which in the past were not possible, such as working on the playground." adolescent $Y$ added that:

Since Street Action, I became an animator. I work on the municipality playground and organize activities for the youth service. This resulted from Street Action. [Researcher: and what's the difference with the past, why via Street Action?]. Because we got the chance, we just got the chance.

\subsection{Non-Formal and Experiential Learning}

The second category of conditions relates to the process of non-formal and experiential learning through a practice-based approach. It includes (1) taking responsibilities gradually and learning by doing, and (2) professional and interactive guidance.

\subsubsection{Taking Responsibilities Gradually and Learning by Doing}

Our results showed the importance of providing experiences of success through volunteering as well as the importance of there being a gradual take up of responsibilities, thereby increasing adolescents' engagement at their own pace.

You have to think ahead, think about a structure. Which is the next dose they need in a manner of speaking, and how are we going to offer that to them? We also need this for ourselves, to be careful not to go too fast because our expectations are often too high. If you determine achievable goals in specific periods, then you know, OK, I can't ask for more, because those were our goals we put forward and we discussed it with the adolescents. You need structure, both for the participants as well as for the organizers. (Community sport worker 1 )

In addition, learning opportunities were provided by directly linking theory to practice (e.g., involvement as an apprentice within an animator formation course). It is worth pointing out that the two successful programs were both collaborating with a youth welfare work organization in order to develop their program in a more systematic way. A key sufficient condition here was the organization of a specific youth animator training course for the target group which consisted of 60 hours of training (over 8 consecutive days) and was followed by an apprenticeship of 60 hours. During and after this course, 
adolescents were actively encouraged to take on responsibilities in the design and provision of the community sport offer and were guided by one or more professionals from the local sport and/or social partners and the youth work organization.

The animator course is absolutely a good base, I think the theory is sufficient and the rest is growing and learning by doing, is experiencing by doing, by standing in the field. (Community sport worker 1 )

Another youth worker (2) recounted:

We wanted to offer them a training in order to strengthen them in taking responsibilities and actually the youth animator course fitted the best with what they were going to do within Street Action, because it goes beyond sport....By giving them an animation course, we are also offering them different opportunities [e.g., group binding activities].

In contrast, in one of the unsuccessful projects, nothing was done to stimulate adolescents to take up responsibilities gradually. More specifically, they provided, for example, a shuttle service from the youth center to the sports center and did nothing to stimulate the adolescents to organize transportation for themselves, such as biking to the center. As a result, adolescents expected a readymade leisure activity where everything was done for them, rather than be responsible and motivated themselves. Furthermore, the program organizers also indicated that the responsibilities must be commensurate with the capabilities of the adolescents. In other words, responsibilities and voluntary tasks must be challenging, but at the same time achievable.

Besides, it was argued that programs need to think in advance how they can encourage interested adolescents to integrate into the organizations after the project has ended (e.g., as a community sport coach or youth animator). In this respect, according to a program organizer, the project has to be part of an integral and coordinated policy strategy. Emphasizing this point, one of the district managers stated:

In the past, different projects for vulnerable groups were organized in our city. But they were always short term and with this target group that's difficult. Then you involve them during a short period, and then it stops and nothing else is organized, or a new project has started, with other counselors, again building up confidence and that's really difficult with this target group ... From a district management perspective, I think we need to evolve to such partnerships (e.g., community sport service and social partners).... It's just a matter to work integral and involve expertise from different domains. As district management, we need to evolve to become coordinators of big projects.

\subsubsection{Professional and Interactive Guidance}

According to the respondents, it became clear that involving professionals from other sectors with specific expertise in dealing with disadvantaged adolescents such as community sport, youth (welfare) work or street work was one of the most important factors leading to successful programs. Different program organizers argued that the implementation of this type of expertise and competences is essential to create a bond of trust and to construct supportive relationships of equality. It allowed the creation of a safe and challenging environment where adolescents can be themselves; unafraid of making mistakes, receiving individual attention and getting the chance to resolve mistakes, in order to develop themselves. Additionally, there is an emphasis on frequent feedback and reflection throughout the course of the program, as was indicated by one of the community sport workers interviewed:

It is important in the course to learn how to stand in front of a group and giving the adolescents constant feedback. After each activity, there is a short moment of evaluation with the coaches. Often I start with asking them how they feel about it. I think it's important that they learn to assess themselves, that they wonder "did I do well or wrong"...and that we discuss together. (Community sport worker 1)

Another worker with expertise recounted:

During the project, we asked them regularly on an informal way what they think of the activities and their performance, but we also organized different individual evaluations to give them the chance to give their opinion and to give them feedback with regard to their competences. I think they really appreciate this support. (Prevention worker 1)

\section{Adolescent $A$ added:}

When we did something wrong, they go about it in a different way [in comparison with school] and we calmed down. So, yeah, it is difficult to explain, but they handled us in such a specific way, that we remained calm.

Although involving specialists in youth programming seems a very logical condition, in some of the projects they did not see the need for implementing specific expertise and knowledge. As a consequence, they did not succeed in retaining disadvantaged adolescents in their program. For instance, according to a member of staff responsible for the local sport service of one municipality, their project failed because although, at first, a bond had been created between adolescents and a sport promoter, once this sport promoter stopped due to a lack of time, the adolescents dropped out of the project as there were no means to replace her. 
Another sufficient condition is that the youth work guidance approach used in both successful Street Action programs included the use of different character roles to be played by the adolescents which related to being a volunteer. Each character portrayed different competences. These competences included either being a friend (e.g., respect, support, handling differences), a clown (e.g., entertaining, motivating, valuing), a guide (e.g., taking leadership, making oneself understood, managing a group, being a role model), a referee (e.g., taking responsibility, setting boundaries, being consistent, handling conflicts), builder (e.g., organizing, cooperating, taking initiative, being independent) and an inventor (e.g., being creative, being flexible, adapting oneself to unexpected circumstances). The approach was seen by the adolescents as very useful and educational and helped them to better understand the different roles a coach has to play. The roles were the thread throughout the whole training course and apprenticeship. Participants were encouraged to reflect on their own competences according to these roles. The adolescents indicated that this increased their insight into themselves. Adolescent $Y$ stated:

We got a booklet, with tips and different games and an evaluation form and at the end of the week we evaluated the things where we are good at, the things that went worse, and what were the next steps. So we were redirected. In this booklet, our strengths were listed, as well as our points of improvement, where we needed to work on.

\section{Adolescent B added:}

You are learning from your own mistakes. When you do something wrong, there is always somebody who can point you "if you do it in another way, that will be much easier."

This practice-based approach of the program was highly appreciated by the participants.

Yes, we laughed a lot. They were nice people and they taught us. How would I say? It was not a piece of paper and a ball pen, but we got different tasks and from this, the theory followed and that was well done. (Adolescent Y)

When school was the same as this training, I would love to go to school. (Adolescent B)

The adolescents, however, were critical of the use of specific terms (such as a 'course') as it created negative expectations of a school setting.

Course and apprenticeship, these are big words. When you think about a course, you think about a book that you have to learn by heart and then an ap- prenticeship and certificate... I would call it animator training or something like that. (Adolescent $Y$ )

The course involves games etc. At the beginning, we thought we would get theoretical lessons, sheets of paper etc. But no, we did games and that was fun. Learning by playing. (Adolescent E)

\subsection{Perceived Human Capital Developmental Outcomes}

Adolescents and program organizers also reported a variety of outcomes of adolescents' involvement in the programs. Among others, these related to (perceived) behavioral changes. Through their involvement as volunteers in the programs, adolescents indicated that they (1) had started taking more initiative and felt more responsible, (2) had taken up social responsibilities, (3) had taken command of the project by taking the initiative to motivate others to become involved as well, (4) had been able to expand their network. This is clarified with the following quotes:

At a given moment during the project, the adolescents had to perform a presentation for the mayor and aldermen. Where formerly they had never visited the town hall, now they just performed their presentation. (Street worker 1)

The first day by the start of the trajectory, there was one adolescent. Finally, that number became 3 . Then the adolescents started calling their friends all day long and the day after 9 participants showed up. So, in fact, the adolescents had a huge contribution in that. We appreciated that they showed engagement, because from that moment on we knew they were really willing to start the trajectory. Because when they don't want to take part, they would not be that devoted. (Sport promotor 1)

The successful programs also resulted in adolescents highlighting positive experiences with official institutions. A street worker summarized this as follows.

I noticed an increased initiative and responsibility of some adolescents. If you see, starting their own youth centre involves many different forms and protocols and as a result many adolescents dropped out. But what I have seen now, is because of their training within Street Action, the adolescents start taking more responsibilities within the Street Action program and start experiencing that taking the step to the town hall and their youth centre is easier to do. (Street worker 1 )

Other perceived human capital outcomes by the adolescents were related to the fact that, through their involvement as a volunteer in the programs, adolescents indicated that they: (1) had become even more motivated for taking these responsibilities, (2) had more positive 
self-image, higher self-efficacy and self-esteem, (3) felt more respected in their neighbourhood (from friends, parents, others), (4) experienced recognition from different municipal services and institutions, (5) had fun with friends, (6) developed other social and personal competences (e.g., taking more personal and social responsibility), (7) experienced success, (8) learnt that success does not happen by itself, but can be made, and (9) experienced positive emotions linked to success. These findings were endorsed by the program organizers. This is clarified with the following quotes:

Adolescents taking more responsibilities is positive for their self-development, discovering that they are also able to have more capabilities than was assumed at that time. For example, an adolescent who is not doing very well at school, but turned out to be one of our best coaches and even took engagement in other activities and projects in the municipality. At the beginning, he was just somebody who went to school and hung around on the streets and never succeeded at school. Now he is an active volunteer in the municipality. Now he has to realize for himself, "I'm able to do something, I have my skills". (Street worker 1)

We once organized a meeting in the town hall, and at first I thought it would be too difficult for them. But in fact the adolescents reacted in a very positive way and appreciated it to be taken seriously and that we were concerned about how they felt and how things went. (Prevention worker 1)

You learn to be less aggressive, you have to keep control of yourself towards little children....You learn how to work together, you learn to be sociable....We also learned how to improvise, during our trajectory. We had to perform a play without thinking in advance. You got your task and you had to invent a drama immediately and you can only learning that by doing. (adolescent $\mathrm{Y}$ )

\section{Discussion and Conclusion}

The purpose of the present study was twofold: (1) to assess the conditions necessary to development the human capital of disadvantaged adolescents through volunteering in community sport, and (2) to assess to what extent human capital can be developed. The need for this study was prompted by the current, limited, empirical evidence concerning sport volunteering's potential for human capital developmental of vulnerable adolescents and the underlying conditions required for such a development.

\section{1. (Sufficient) Conditions}

It has been indicated that reaching and retaining disadvantaged adolescents constitutes the first necessary condition for working with them towards broader developmental and societal outcomes (Haudenhuyse et al., 2012; Patricksson, 1995). While this seems like a very logical first step, the present study in community sport programs confirms that this is a challenging objective. With regard to community sport programs, however, this is a remarkable finding as different authors (e.g., Marlier et al., 2014; Theeboom \& De Maesschalck, 2006) have indicated that community sports have been specifically set up to reach the 'hard to reach'. In the eight pilot projects it became clear that a majority $(n=6)$ of the programs experienced difficulties in meeting different necessary conditions, and as such, to attract and retain disadvantaged adolescents as mere participants. More specifically, these related to similar findings in other sport and youth work contexts (Buelens, Theeboom, Vertonghen, \& De Martelaer, 2015; Coalter, 2007; Gambone \& Arbreton, 1997) and included amongst others (1) setting up a top-down program without prior involvement of the target group, (2) lacking clearly defined goals of the program, (3) difficulties in lowering thresholds, and (4) programs not being part of an integral and coordinated policy strategy. In addition, it turned out that the main reason why these programs were not able to go beyond these necessary conditions, was simply because they did not fully recognize that they are distinct from sufficient conditions, which are needed to provide developmental opportunities through volunteering. This means that they were primarily assuming that organizing sport activities for their target group would be sufficient to engage them in volunteering and as a result develop them. It can be concluded that the Street Action pilot programs which adopted such dominant approach, were characterized by higher levels of failure in terms of attracting adolescents as volunteers and their development, even though some of them were able to engage disadvantaged adolescents to a certain extent in the community sport as participants. This point of view concurs with the often taken for granted belief or storyline that positive developmental outcomes may be attributed merely to participation in sport. For example, Green (2008) argued that: "the belief that sport builds character is so ingrained that neither providers nor participants feel it necessary to do anything more than to provide opportunities. The benefits are thought to accrue to participants merely as a function of the opportunity" (p. 132). However, similar to what has been reported by others, results showed that attracting adolescents and organizing sport activities for them is not sufficient to enable developmental opportunities. Research has just begun to unravel these sufficient conditions (Coalter, 2012; Draper \& Coalter, 2016; Sandford et al., 2006; Spaaij, 2012; Spaaij \& Jeanes, 2013). The present study contributes, to a certain extent, to the insight into the sufficient conditions for programs that are initiated in more 'traditional' sport structures (i.e., municipal community sport services). These structures have, at least in Flanders, no real track record in focusing on this type of adolescent, let alone do they have experi- 
ence in using sport from a youth development perspective. Based on the findings within two programs, inductive analysis identified two categories of sufficient conditions, being (1) valuing and recognizing adolescents, and (2) non-formal and experiential learning. The first category included four aspects: (a) bottom-up approach, (b) personal involvement, (c) reinforcing environment, and (d) official recognition. The second category included (1) taking responsibilities gradually and learning by doing, and (2) professional and interactive guidance.

\subsection{Generalization of Conditions and their Interrelatedness}

Similar necessary and sufficient conditions were identified in the different pilot programs, emphasized by the different actors involved. These conditions, furthermore, confirm research in specific sport for development programs (Coalter, 2012; Haudenhuyse et al., 2012; Schaillée, 2016; Spaaij, 2012) and youth work (Coussée, Roets, \& De Bie, 2009; Gambone \& Arbreton, 1997; Hurley \& Treacy, 1993; Jones \& Deutsch, 2010; Witt \& Crompton, 1997). For example, the European Commission (2014) summarized four categories of specific key feature methods used by youth work: (1) non-formal and informal learning, (2) participatory and/or experiential pedagogy, (3) relationship-based activities (learning as a social activity with others), (4) mentoring and/or peer support. Gradually involving adolescents from an early age to ascertain a commitment with the organisation when they grow older is an approach often used in traditional youth work (i.e., scouting, Coussée et al., 2009) and youth development programs (Dworkin et al., 2003; McLaughlin, 2000; Roth et al., 1998). In addition, researchers' own previous research related to disadvantaged adolescents' volunteering in sport, showed similar conditions in practices both inside (sport clubs) and outside (youth work) primarily traditional sport settings. Findings stressed the importance of establishing good relationships with the target group and striving for their maximal involvement in all aspects of the programs (Buelens et al., 2015; Buelens, Theeboom, Vertonghen, \& De Martelaer, in review). This means a generalization can be made for different practices in different contexts and confirms previous research of Pawson (2001) stating that there is generalization and specificity in different social practices at the same time, which he referred to as a 'tailored transferable theory' (i.e., "this program theory works in these respects, for these subjects, in these kinds of situations", Pawson, 2001, p. 4). In this respect, he argued a shift in the analysis and understanding of social intervention programs from 'families of programs' to 'families of mechanisms' is needed (Pawson, 2006). From the present research it also has become clear that different conditions underlying the two identified categories of sufficient conditions are interrelated. Adolescents can develop their human capital through non-formal and experiential learning which can be facilitated when they feel valued and recognized. Besides, adolescents' active involvement is also interrelated with the strengthening of their sense of belonging. They also expressed feelings of confidence and being respected which is interrelated with perceptions of equality.

In addition, from the present research, it can also be concluded that a gray area exists when it comes to retaining disadvantaged adolescents in sport. This can be illustrated with the comparison of recent research on sport club participation among disadvantaged adolescents in Flanders. In that study, Haudenhuyse et al. (2013b) categorized some conditions as 'necessary' that in the present study are described as 'sufficient'. After all, retaining adolescents of this target group often requires conditions in which they feel a sense of belonging, which in turn can be provided by creating opportunities to be actively involved, in other words, by complying with sufficient conditions. On the contrary, various studies (e.g., Day \& Devlin, 1998; Smith, 2010) reported different conditions that were perceived to be sufficient, such as retaining adolescents in sport and facilitating professional support. However, findings in the present study revealed that although those conditions are very important, they cannot always be labeled as sufficient.

Furthermore, findings of the present study showed that most sport professionals of the local sport authorities involved were not well trained to work towards specific developmental aims. As noted in most of the investigated practices, there was a distinct need to have the support of professionals in youth development to deal with these issues. Within the two 'successful' practices, expertise regarding the provision of sufficient conditions for human capital development of the target group through volunteering in sport was largely found in youth work. This provides evidence that the abovementioned similarities within the identified sufficient conditions are rooted in the fact that these practices rely on systematic approaches and tools from youth work. This comes as no surprise, given the fact that adolescents (and their development) can be regarded as the primary goal of youth work. This is in contrast with youth sport contexts which often emphasize sport participation and performance. Furthermore, because of structural and logistical challenges a majority of pilot programs were facing, the youth professionals involved in those programs could not prioritize this type of work. In this respect, questions can be asked regarding whether traditional sport settings actually provide the best setting for a critical empowerment approach, not only because pursuing developmental goals, for a long time has not been the primary mission of traditional sport settings, but also because sport professionals often are not trained for developing social relationships, the strength of which has been identified as largely determining the success of sport-based social interventions Hartmann (2003). Theeboom et al. (2010) argued that it is already a major challenge for sport policy, in general, to focus on engaging adolescents in vulnerable situations. 
However, youth work, as such, cannot be viewed as 'the holy grail' for (critical) youth development since, despite its expertise regarding youth development, it is not accessible to all young people (Coussée, 2006; Smits, 2004). Although different youth-work initiatives targeting socially vulnerable adolescents exist, it has been noted that attempts to reach these groups did not lead to the desired effects or even generated counterproductive ones (Coussée, 2008; Coussée et al., 2009). Pease (2002) argued that it is crucial for both marginalized and non-marginalized adolescents to come in contact with alternative discourses and for new people to be able to produce new knowledge and more 'alternative and free ways of living'. In addition, according to Coussée and colleagues (2009) cross-connections that search for new communalities between young people on a thematic base (e.g., in the sphere of sport), may broaden perspectives without losing youth work's safe environment. Since one of the advantages of sport and sport for development practices is that they often seem to be more capable than other socio-cultural activities in attracting young people independently of their socioeconomic background (Crabbé, 2006; Feinstein, Bynner, \& Duckworth, 2006; Haudenhuyse et al., 2013a; Hellison \& Walsh, 2002; Spaaij, 2009; Vanhoutte, 2007), sport is viewed by many as primarily an activity attracting many adolescents, including disadvantaged adolescents. This might suggest that sport is nothing more than a hook. However, in this respect, there is a need to investigate specific additional benefits linked to youth involvement in sport. After all, it provides a good setting in which participants can , among other things, learn by doing and through (resolving) their own mistakes; it provides a setting where responsibilities can be given and active involvement can be encouraged more easily than in other settings, such as in school and labor market. It is far more feasible to involve a young member to be an assistant coach in sport, than to give him or her, for example, the status of 'assistant school teacher'. In this respect, the present study highlighted the potential of collaborating efforts between the sector of sport and youth work. The authors have reported elsewhere that, to date, this collaboration between both sectors in Flanders is, in most cases, sorely lacking (Buelens et al., 2015). In this context, we might suggest thinking about a new type of organizational format which combines both traditions as an important practical implication. A concept that shows resemblance to what became known in Germany in the early 1980's as 'sportliche sozialarbeit' (sport social work). In this respect, it is worthwhile to investigate what is needed to introduce this type of alternative format in which relevant features of sport (e.g., interactions with significant others on different levels) and youth work (e.g., focus on the individual instead of their (athletic) performance) can come together.

Consequently, the question is whether the sport sector should incorporate more youth work-related strategies or whether youth work should make use of sport as an activity in which they implement their specific approaches. It is yet to be seen which is the most feasible direction. Further research is needed. In this respect, the present study emphasizes the idea that volunteering can be seen as a key method as it facilitates the interactions of disadvantaged adolescents with significant others. Findings indicated that the quality of social relationships developed during a program, one of the critical success factors of development programs for disadvantaged adolescents (Draper \& Coalter, 2016), can be facilitated through volunteering. First, adolescents could learn both from and with each other as well as from providers and coaches during their apprenticeships. Second, the disadvantaged adolescents were in the position to learn from guiding younger children. This corresponds with findings from Brunelle, Danish and Forneris (2007) that teaching life skills to younger children is a socially responsible activity that also enables adolescents to gain a sense of competence and self-efficacy. In addition, the relationships adolescents could have formed with the younger children may have further contributed to their ability to have concern for others. Third, adolescents learned through interactions with other (older) volunteers, the board, parents, and children. This is in line with Omoto and Snyder (1990) who suggest, in their volunteer process model, that engaging in a volunteer experience gives adolescents an experiential opportunity to learn about themselves and make attributions and assumptions about their roles as helpers. This was further confirmed by findings in the two programs where adolescents learned consciously through their role as 'animators'.

\subsection{Human Capital Developmental Outcomes and Critical Empowerment}

Results also showed the achievement of two types of perceived human capital developmental outcomes through fulfilling the abovementioned sufficient conditions. Thereby, disadvantaged adolescents' human capital is seen as the development of a broad set of resources. Adolescents indicated to develop both personal (e.g., taking initiative, taking personal responsibility) as well as interpersonal competences (e.g., working together, communication, dealing with feedback).

As indicated in the introduction, apart from a strategy to tackle social vulnerability on an individual level, another strategy relates to working towards structural changes at an institutional level (Coakley, 2011; Haudenhuyse et al., 2012, 2013a; Kelly, 2011; Vettenburg, 1998). Needless to say, this is not an easy thing to do. It goes well beyond the scope of most programs working with disadvantaged adolescents. It requires an integrated approach to implement measures and to set up initiatives with other relevant policy areas (e.g., education, welfare, youth,)-each with their own specific knowledge, experiences and expertise-to break out of the vicious circle of poverty, problematic welfare and low educational achievement of an increasing number of young 
people. It also relates to what others have labeled as critical approaches of youth development (i.e., Ginwright \& Cammarota, 2002; Hartmann \& Kwauk, 2011; Iwasaki, 2015). The assumption is that these type of approaches can empower participants to not only understand existing social hierarchy, power relations, and social inequalities, but also to critically take part in the transformation of their own position within society (i.e., by becoming critical individuals). In the introduction, the authors described the six key dimensions of critical youth empowerment (Jennings et al., 2006). From the present study it became clear that the underlying sufficient conditions of the two successful practices did not facilitate all of these dimensions, however, the first three certainly did. And to some extent, initial steps towards participation in socio-political processes were made as well as in some programs adolescents were invited in the town hall to express their ideas (dimension 4, engagement in critical reflection on interpersonal and socio-political processes). The fact that the programs were organized within municipal institutions is relevant and in line with findings of Iwasaki (2015) who stated that:

the strategic use of youth leadership with the support of community partners/stakeholders seems essential to facilitate social/systems changes in order to more effectively inspire and support marginalized youths who are at high-risk of a variety of life challenges. The power of youth in mobilizing systems/social changes should not be underestimated. (p. 11)

By focusing on becoming involved as a volunteer, the two programs incorporating a systematic approach seem to implicitly aim for a more critical approach to youth development. Although not all types of volunteering can be referred to as critical, the fact that participants were encouraged to be actively involved from the onset of the programs under study, shows their intention to motivate adolescents to take control and to change things themselves. The successful programs started from adolescents' needs and allowed them to come in contact with official institutions in a positive way. In addition, by allowing adolescents to organize their own activities in the programs (e.g., organizing (sport) activities in their own neighbourhood for other disadvantaged children and adolescents), a setting was created where they experienced that through their involvement as a volunteer they could change things in their own neighbourhoods and even feel that they were making a meaningful contribution to society in general. And by making use of selfreflection techniques among adolescents (e.g., through visualization of their own competences), they were able to critically reflect on their own situation and to progress. However, improving adolescents' vulnerable situation is no individual responsibility (Vettenburg, 1998). The present study offers evidence to call for realism with regard to critical empowerment expectations that adolescents can be emancipated to affect ruling social hi- erarchy and power relations by themselves (Hartmann \& Kwauk, 2011). As became clear throughout the study, for the more radical changes of critical youth empowerment (dimensions 5 and 6; 5: participation in sociopolitical processes to affect change, and 6: integrated individual- and community-level empowerment) radical changes are needed at the institutional level. Future research is needed to investigate how society's institutions can facilitate the provision of equal developmental opportunities for disadvantaged adolescents. Furthermore, by interpreting these findings and conclusions, caution is also warranted since only two programs managed to attract disadvantaged adolescents which could be a clear indication of exclusionary processes. This means critical youth empowerment was not reached in six out of the eight programs and one can wonder if these adolescents became even more vulnerable when the programs failed to keep them engaged.

\subsection{Limitations and Other Future Research Directions}

Although the present study delivers insight in the sufficient conditions underlying volunteering in community sport programs and related human capital outcomes for disadvantaged adolescents, our findings are based on only two community programs. This implies the identified categories need to be studied in future research. In this regard, using other research approaches might be useful. In the present study, researchers used an IPA approach for data collection and analysis as the aim was understanding the lived experiences from both a provider's and a participant's perspective and with how interviewees themselves make sense of their experiences. However, other research approaches, such as a realist synthesis (Herens, Wagemakers, Vaandrager, van Ophem, \& Koelen, 2016) focussing on a more structured and systematic evaluation might generate additional insights. In addition, assigning (community) sport programs to a theoretical concept and then systematically carrying out an analysis of topics deductively derived from the present study and other current research would also be feasible. In addition, it also might be useful for future research to use the same strategy of interviewing and focus groups for investigating different specific forms of capital.

The focus of the present study has mainly been on the perspectives of those providing and supporting opportunities for volunteering in community sport and those partaking in it (i.e., mentoring relationships). However, such processes always take place in relation to different contexts. Community sport programs for adolescents should never lose sight of the social, political and/or organizational setting in which these interventions take place. Societal institutions, such as schools, the labor market, and the family context were not directly studied in this study. This is a limitation since societal institutions are the major maintainers and regenerators of social vulnerability and as a result, their impact on the lives of adolescents is of immeasurable significance (e.g., 
Kay \& Spaaij, 2012; Padoan, 2010). In the present study information about such key institutions was mainly indirectly obtained from the perspectives of adolescents and professionals. But a further elaboration of these interactions is needed in further research. And although it was not within the scope of the present study, it would be interesting to see to what extent all these experiences as a volunteer in community sport can have an impact on these adolescents' choices they make in their lives in general, as well as on the change in opportunities they might get in relation to social networks, education, and work. Besides, in the present study, we only included adolescents who were actively involved and those who were organizing and supporting the different programs. As a result, dropouts were not included, which might have led to a distorted positive image regarding our findings. A critique shared by others, such as Hartmann and Kwauk (2011). It would be worthwhile to learn from the views and experiences of those who did not want to participate or are not participating any longer. In addition, looking at sport-developmental programs for adolescents should never lose sight of maturation effects nor disregard the social, political and/or organizational setting in which these interventions take place. Finally, even though, in the present study focus groups were explicitly chosen for their advantages with regard to disadvantaged adolescents (Smithson, 2000), several dangers of conducting focus groups with vulnerable groups also exist. Therefore, it might be useful for future research to conduct semi-structured interviews with disadvantaged adolescents as well.

\section{Acknowledgements}

Funding for this research was provided by ISB vzw. The authors would like to thank the participating youngsters and organizers in this study. They also want to thank the anonymous reviewers for their valuable comments on earlier versions of this article as well as Dr. Reinhard Haudenhuyse for his valuable advice.

\section{Conflict of Interests}

The authors declare no conflict of interests.

\section{References}

Bandura, A. (1977). Social learning theory.

Becker, G. (1964). Human capital national bureau of economic research. New York.

Benson, P. L. (2006). All kids are our kids: What communities must do to raise caring and responsible children and adolescents (2nd ed.). San Francisco, CA: JosseyBass.

Brunelle, J., Danish, S. J., \& Forneris, T. (2007). The impact of a sport-based life skill program on adolescent prosocial values. Applied developmental science, 11(1), 43-55.
Buelens, E., Theeboom, M., Vertonghen, J., \& De Martelaer, K. (2015). Socially vulnerable youths and volunteering in sport. Analysing a Brussels training programme for young football coaches. Social Inclusion, 3(3), 82-97.

Buelens, E., Theeboom, M., Vertonghen, J., \& De Martelaer, K. (in review). Volunteering of socially vulnerable youths in Flemish sport clubs. Investigating conditions and perceived human capital developmental outcomes.

Bynner, J. (2005). Rethinking the youth phase of the lifecourse: The case for emerging adulthood? Journal of Youth Studies, 8(4), 367-384.

Catalano, R. F., Berglund, M. L., Ryan, J. A., Lonczak, H. S., \& Hawkins, J. D. (2004). Positive youth development in the United States: research findings on evaluations of positive youth development programs. Annals of the American Academy of Political and Social Science, 591, 98-124.

Coakley, J. (2011). Youth sports: What counts as "positive development"? Journal of Sport \& Social Issues, 35(3), 306-324.

Coalter, F. (2001). Realising the potential. The case for cultural services: Sport. London Local Government Association.

Coalter, F. (2007). A wider social role for sport: Who's keeping the score? (1st ed.). London: Routledge.

Coalter, F. (2011). Sport development's contribution to social policy objectives. The difficult relationship between politics and evidence. In B. Houlihan \& M. Green (Eds.), Routledge handbook of sports development (1st ed., pp. 561-578). London: Routledge.

Coalter, F. (2012). "There is loads of relationships here": Developing a programme theory for sport-for-change programmes. International Review for the Sociology of Sport, 48(5), 594-612.

Coalter, F. (2013). Sport for development: What game are we playing? (1st ed.). London: Routledge.

Coussée, F. (2006). De pedagogiek van het jeugdwerk. Academia Press.

Coussée, F. (2008). A century of youth work policy. Academia Press.

Coussée, F., Roets, G., \& De Bie, M. (2009). Empowering the powerful: Challenging hidden processes of marginalization in youth work policy and practice in Belgium. Critical Social Policy, 29(3), 421-442. doi:10.1177/0261018309105178

Crabbé, T. (2006). Reaching the 'hard to reach': Engagement, relationship building and social control in sport based social inclusion work. International Journal of Sport Management and Marketing, 2(1/2), 27-40.

Damon, W. (2004). What is positive youth development? The Annals of the American Academy of Political and Social Science, 591, 13-24.

Darnell, S. C. (2007). Playing with race: Right to play and the production of whiteness in "development through sport". Sport in Society, 10(4), 560-579.

Darnell, S. C. (2010). Power, politics and "sport for devel- 
opment and peace": Investigating the utility of sport for international development. Sociology of Sport Journal, 27(1), 54-75.

Day, K., \& Devlin, R. A. (1998). The payoff to work without pay: Volunteer work as an investment in human capital. Canadian Journal of Economics, 31(5), 1179-1191.

Dierckx, D., Coene, J., Van Haarlem, A., \& Raeymaekers, P. (2013). Armoede en sociale uits/uiting. Jaarboek 2013 [Poverty and social exclusion. 2013 annual] (1st ed.). Leuven: Acco.

Draper, C. E., \& Coalter, F. (2016). "There's just something about this club. It's been my family." An analysis of the experiences of youth in a South African sport-for-development programme. International Review for the Sociology of Sport, 51(1), 44-60.

Dworkin, J. B., Larson, R., \& Hansen, D. (2003). Adolescents' accounts of growth experiences in youth activities. Journal of Youth and Adolescence, 32(1), 17-26. doi:10.1023/A:1021076222321

Eley, D., \& Kirk, D. (2002). Developing citizenship through sport: The impact of a sport-based volunteer programme on young sport leaders. Sport, Education and Society, 7(2), 151-166.

Eurofound. (2012). NEETs-Young people not in employment, education or training: Characteristics, costs and policy responses in Europe. Luxembourg: Publications Office of the European Union.

European Commission. (2014). Working with young people: The value of youth work in the European Union. Retrieved from http://ec.europa.eu/assets/ eac/youth/library/study/youth-work-report_en.pdf

Feinstein, L., Bynner, J., \& Duckworth, K. (2006). Young people's leisure contexts and their relation to adult outcomes. Journal of Youth Studies, 9(3), 305-327.

Freire, P. (1993). Pedagogy of the oppressed (Rev. ed.). New York: Continuum, 1970.

Gambone, M. A., \& Arbreton, A. J. (1997). Safe havens: The contributions of youth organizations to healthy adolescent development.

Ginwright, S., \& Cammarota, J. (2002). New terrain in youth development: The promise of a social justice approach. Social Justice, 29, 82-95.

Giulianotti, R. (2004). Human rights, globalization and sentimental education: The case of sport. Sport in Society, 7(3), 355-369.

Glover, T. D., \& Hemingway, J. L. (2005). Locating leisure in the social capital literature. Journal of Leisure Research, 34(4), 387-401.

Gould, D., \& Carson, S. (2008). Life skills development through sport: Current status and future directions. International Review of Sport and Exercise Psychology, 1(1), 58-78.

Green, C. (2008). Sport as an agent for social and personal change. In V. Girginov (Ed.), Management of Sports Development (pp. 129-146). Oxford: Butterworth-Heinemann.

Grineski, S. (1996). Cooperative learning in physical education. Human Kinetics Publishers.
Guest, A. M. (2009). The diffusion of developmentthrough-sport: Analysing the history and practice of the Olympic Movement's grassroots outreach to Africa. Sport in Society, 12(10), 1336-1352.

Hartmann, D. (2003). Theorizing sport as social intervention: A view from the grassroots. Quest, 55, 118-140.

Hartmann, D., \& Kwauk, K. (2011). Sport and development: An overview, critique, and reconstruction. Journal of Sport and Social Issues, 35(3), 284-305.

Haudenhuyse, R., \& Theeboom, M. (2012). The potential of sports for socially vulnerable youth. VUB Press.

Haudenhuyse, R., Theeboom, M., \& Coalter, F. (2012). The potential of sports-based social interventions for vulnerable youth: Implications for sport coaches and youth workers. Journal of Youth Studies, 15(4), 437-454.

Haudenhuyse, R, Theeboom, M., \& Nols, Z. (2013a). Sports-based interventions for socially vulnerable youth: Towards well-defined interventions with easyto-follow outcomes? International Review for the Sociology of Sport, 48(4), 471-484.

Haudenhuyse, R., Theeboom, M., Nols, Z., \& Coussée, F. (2013b). Wij Sporten Mee. Verkennend onderzoek naar de rol van sportclubs in het leven van maatschappelijk kwetsbare jongeren. Demos.

Haudenhuyse, R., Theeboom, M., \& Skille, E. A. (2014). Towards understanding the potential of sports-based practices for socially vulnerable youth. Sport in Society, 17(2), 139-156.

Hellison, D., \& Walsh, D. (2002). Responsibility-based youth programs evaluation: Investigating the investigations. Quest, 54(4), 292-307.

Herens, M., Wagemakers, A., Vaandrager, L., van Ophem, J., \& Koelen, M. (2016). Contexts, mechanisms, and outcomes that matter in Dutch community-based physical activity programs targeting socially vulnerable groups. Evaluation \& the Health Professions, 0163278716652940.

Hirschi, T. (2009). Causes of delinquency. New Jersey: Transaction Publishers.

Hogan, D., \& Owen, D. (2000). Social capital, active citizenship ad political equality in Australia. In I. Winter (Ed.), Social capital and public policy in Australia (pp. 74-104). Melbourne: Australian Institute of Family Studies.

Hurley, L., \& Treacy, D. (1993). Models of youth work: A sociological framework. Dublin: Irish Youth Work Press.

Husserl, E. (1970). The crisis of European sciences and transcendental phenomenology: An introduction to phenomenological philosophy. Northwestern University Press.

Hylton, K., \& Totten, M. (2008). Community sports development. In K. Hylton \& P. Braham (Eds.), Sports development, policy, process and Practice (pp. 17-77). London: Routledge.

Iwasaki, Y. (2015). The role of youth engagement in positive youth development and social justice youth de- 
velopment for high-risk, marginalised youth. International Journal of Adolescence and Youth, 1-12.

Jennings, L. B., \& Green, J. L. (1999). Locating democratizing and transformative practices within classroom discourse. Journal of Classroom Interaction, 34(2), i-iv.

Jennings, L. B., Parra-Medina, D. M., Hilfinger-Messias, D. K., \& McLoughlin, K. (2006). Toward a critical social theory of youth empowerment. Journal of Community Practice, 14(1/2), 31-55.

Jones, N., \& Deutsch, N. (2010). Relational strategies in after-school settings: How staff-youth relationships support positive development. Youth and Society, 43(4), 1381-1406.

Kay, T., \& Bradbury, S. (2009). Youth sport volunteering: Developing social capital? Sport, Education and Society, 14(1), 121-140.

Kay, T., \& Spaaij, R. (2012). The mediating effects of family on sport in international development contexts. International Review for the Sociology of Sport, 47(1), 77-94.

Kelly, L. (2011). 'Social inclusion' through sports-based interventions? Critical Social Policy, 31(1), 126-150.

Kidd, B. (2008). A new social movement: Sport for development and peace. Sport in Society, 11(4), 370-380.

Kolb, D. A. (1984) Experiential learning: Experience as the source of learning and development. Englewood Cliffs, NJ: Prentice-Hall.

Koning Boudewijnstichting. (2015). Het vrijwilligerswerk in België. Kerncijfers [Voluntary work in Belgium. Core figures]. Brussels: Koning Boudewijnstichting.

Krauss, S. E., Hamzah, A., Suandi, T., \& Tamam, E. (2007). Focusing on the 'human' in human capital: Positive youth development as a foundation for maximising human capital investment. Commonwealth Youth and Development, 5(2), 9-20.

Larkin, M., \& Thompson, A. R. (2012). Interpretative phenomenological analysis in mental health and psychotherapy research. In Qualitative research methods in mental health and psychotherapy: A guide for students and practitioners (pp. 99-116). Chichester, UK: Wiley \& Sons.

Lerner, R. M., Lerner, J. V., Almerigi, J. B., Theokas, C., Phelps, E., Gestsdottir, S., . . . \& von Eye, A. (2005). Positive youth development, participation in community youth development programs, and community contributions of fifth-grade adolescents findings from the first wave of the $4-\mathrm{H}$ study of Positive Youth Development. The Journal of Early Adolescence, 25(1), 17-71.

Levermore, R. (2008). Sport: A new engine of development? Progress in Development Studies, 8(2), 183-190.

Marlier, M., Cardon, G., De Bourdeaudhuij, I., \& Willem, A. (2014). A capacity building approach to increase sports participation in disadvantaged urban communities: A multilevel analysis. Journal of Urban Health, 91(6), 1114-1128.
McLaughlin, M. (2000). Community counts: How youth organizations matter for youth development. Washington, DC: Public Education Network.

OECD. (2001). The well-being of nations. The role of human and social capital. Paris: OECD.

Omoto, A. M., \& Snyder, M. (1990). Basic research in action volunteerism and society's response to AIDS. Personality and Social Psychology Bulletin, 16(1), 152-165.

Padoan, P. (2010). A family affair: Intergenerational social mobility across OECD countries. In Economic policy reforms: Going for growth 2010 (pp. 181-198). Paris: OECD.

Palmer, P. J. (2010). The courage to teach: Exploring the inner landscape of a teacher's life. Chichester, UK: Wiley \& Sons.

Patricksson, G. (1995). The significance of sport for society-Health, socialization, economy: A scientific review. Scientific Review part 2. Strasbourg. Council of Europe Press.

Pawson, R. (2001). Evidence based policy: vol. II. The promise of 'realist synthesis'. London: University of London.

Pawson, R. (2006). Evidence-based policy: A realist perspective (1st ed.). London: Sage.

Pease, B. (2002) Rethinking empowerment: A postmodern reappraisal for emancipatory practice. British Journal of Social Work, 32(2), 135-147.

Penner, L. A. (2002). Dispositional and organizational influences on sustained volunteerism: An interactionist perspective. Journal of Social Issues, 58(3), 447-467. doi:10.1111/15404560.00270

Pouw, D., \& Daniels, C. (2001). Sportbuurtwerk in Nederland. Verleden, heden en toekomst [Neighbourhood sport in The Netherlands. Past, present and future]. Arnhem: Nederlands instituut voor Sport en Bewegen.

Rappaport, J. (1987). Terms of empowerment/exemplars of prevention: Toward a theory for community psychology. American Journal of Community Psychology, 15(2), 121-148. doi:10.1007/BF00919275

Risler, E. A., \& Holosko, M. J. (2009). Blueprint for a Youth Empowerment Model (YEM) through volunteerism. In E. S. C. Liu, M. J. Holosko, \& T. Wing Loa (Eds), Youth empowerment and volunteerism. Principles, policies and practices (1st ed., pp. 57-81). Hong Kong: City University of Hong Kong Press.

Roth, J., Brooks-Gunn, J., Murray, L., \& Foster, W. (1998). Promoting healthy adolescents: Synthesis of youth development program evaluations. Journal of Research on Adolescence, 8(4), 423-459. 10.1207/s15327795jra0804_2

Sandford, R. A., Armour, K. M., \& Warmington, P. C. (2006). Re-engaging disaffected youth through physical activity programmes. British Educational Research Journal, 32(2), 251-271.

Schaillée, H. (2016). More than just a game? The potential of sport programmes to foster positive youth de- 
velopment among diasadvantaged girls (PhD Dissertation). Vrije Universiteit Brussel, Belgium.

Schultz, T. W. (1961). Investment in human capital. The American Economic Review, 1-17.

Smith, J. A. (1996). Beyond the divide between cognition and discourse: Using interpretative phenomenological analysis in health psychology. Psychology and Health, 11(2), 261-271.

Smith, J. A. (2004). Reflecting on the development of interpretative phenomenological analysis and its contribution to qualitative research in psychology. Qualitative Research in Psychology, 1(1), 39-54.

Smith, V. (2010). Enhancing employability: Human, cultural, and social capital in an era of turbulent unpredictability. Human Relations, 63(2), 279-300.

Smith, J. A., Flowers, P., \& Larkin, M. (2009). Interpretative phenomenological analysis: Theory. method and research. London: Sage.

Smith, J. A., \& Osborn, M. (2008). Interpretative phenomenological analysis. In J. A. Smith (Ed.), Qualitative psychology: A practical guide to research methods (pp. 53-79). London: Sage.

Smithson, J. (2000). Using and analysing focus groups: limitations and possibilities. International Journal of Social Research Methodology, 3(2), 103-119.

Smits, W. (2004). Bewegen in de sociale, vrijetijds- en culturele ruimte. Eindverslag van het programma beleidsgericht onderzoek 'Maatschappelijke participatie van jongeren' [Acting in social, leisure and cultural areas. End report of the program policy oriented research 'Social participation of adolescents']. Brussels: VUB/TOR.

Sourbron, M., \& Herremans, W. (2013). Jeugdwerkloosheid in Europa: Vlaanderen in een Europees regionaal vergelijkend perspectief [Youth unemployment in Europe: Flanders within a European regional comparative perspective]. Leuven: Steunpunt Werk en Sociale Economie.

Spaaij, R. (2009). Sport as a vehicle for social mobility and regulation of disadvantaged urban youth: Lessons from Rotterdam. International Review for the Sociology of Sport, 44(2/3), 247-264.

Spaaij, R. (2012). Building social and cultural capital among young people in disadvantaged communities: Lessons from a Brazilian sport-based intervention program. Sport, Education and Society, 17, 77-95.

Spaaij, R., \& Jeanes, R. (2013). Education for social change? A Freirean critique of sport for development and peace. Physical Education and Sport Pedagogy, 18(4), 442-457.

Strachan, L., Côté, J., \& Deakin, J. (2011). A new view: Exploring positive youth development in elite sport contexts. Qualitative Research in Sport, Exercise, and Health, 3, 9-32.

Taylor, P. D., Panagoulas, T., \& Nichols, G. (2012). Determinants of sports volunteering and sports volunteer time in England. International Journal of
Sport Policy and Politics, 4(2), 201-220. doi:10.1080/ 19406940.2012.656679

Tesch, R. (1990). Qualitative research analysis types and software tools (1st ed.). London: Routlegde Falmer.

Theeboom, M., Haudenhuyse, R., \& De Knop, P. (2010). Community sports development for socially deprived groups: A wider role for the commercial sports sector? A look at the Flemish situation. Sport in Society, 13(9), 1392-1410.

Theeboom, M., \& de Maesschalck, P. (2006). Sporten om de hoek: Een brede kijk op buurtsport in Vlaanderen [Sport around the corner: a broad view on community sport in Flanders]. Vlaams Instituut voor Sportbeheer en Recreatie beleid.

Van Regenmortel, T. (2002). Empowerment en Maatzorg. Een krachtgerichte psychologische kijk op armoede [Empowerment and tailored care. A powerful psychological approach of poverty]. In J. Vranken, K. De Boyser, D. Geldof, \& G. Van Menxel (Eds.), Armoede en Sociale Uitsluiting, Jaarboek 2002 (1st ed., pp. 71-84). Leuven/leusden: Acco.

Van Regenmortel, T. (2009). Empowerment als uitdagend kader voor sociale inclusie en moderne zorg [Empowerment as a challenging framework for social inclusion and modern care]. Journal of Social Intervention: Theory and Practice, 18(4), pp. 22-42.

Vanhoutte, B. (2007). Doe je mee? Jongeren en participatie aan het verenigingsleven [Are you in? Youth and participation in leisure associations]. In N. Vettenburg, M. Elchardus, \& L. Walgrave (Eds.), Jongeren in cijfers en letters. Bevindingen uit de JOPmonitor 1 [Youngsters in numbers and letters. Findings from JOP-monitor 1], (1st ed., pp. 175-187). Leuven: Lannoo.

Vettenburg, N. (1998). Juvenile delinquency and the cultural characteristics of the family. International Journal of Adolescent Medicine and Health, 10(3), 193-210.

Vettenburg, N. (2011). Jongeren, maatschappelijke kwetsbaarheid en emancipatorisch Jeugdwerk [Youngsters, social vulnerability and emancipatory youth work. In F. Coussée \& C. Mathijssen (Eds.), Uit de marge van het jeugdbeleid. Werken met maatschappelijk kwetsbare jeugd (1st ed., pp. 25-38). Leuven: Acco.

Wilson, J. (2000). Volunteering. Annual Review of Sociology, 26, 215-240.

Witt, P. A., \& Crompton, J. L. (1997). The protective factors framework: A key to programming for benefits and evaluating for results. Journal of Park and Recreation Administration, 15(3), 1-18.

Zimmerman, M. A. (2000). Empowerment theory: Psychological, organizational and community levels of analysis. In J. Rappaport \& E. Seidman (Eds.), Handbook of community psychology (1st ed., pp. 43-63). New York: Kluwer Academic/Plenum Publishers. 


\section{About the Authors}
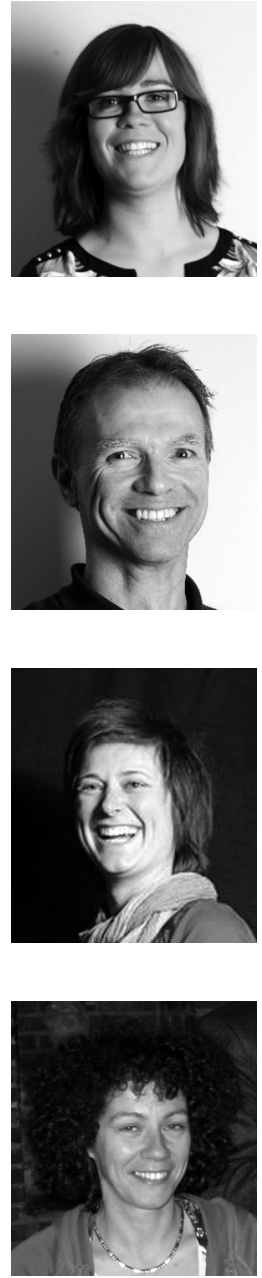

Evi Buelens works as a postdoctoral researcher at the Faculty of Physical Education and Physiotherapy of the Vrije Universiteit Brussel, Belgium (VUB). She is a member of the 'Sport and Society' research group. In September 2016, Evi achieved her PhD in Physical Education and Movement Sciences. Her PhD-study is entitled: 'Exploring the developmental role of volunteering in sport for youngsters in socially vulnerable situations'. Evi's research primarily focuses on volunteering, (critical) youth development, necessary and sufficient conditions, sport, disadvantaged youth and valorisation.

Marc Theeboom works as a full professor at the Faculty of Physical Education and Physiotherapy and the Faculty of Psychology and Educational Sciences of the Vrije Universiteit Brussel, Belgium (VUB). He is chair of the 'Sport and Society' research group. His research primarily focuses on educational and policy-related aspects of (youth) sport in general and specific target groups in particular (e.g. socially deprived youth, ethnic minorities, elderly). He has a special interest in the analysis and evaluation of 'sport development' programmes in which sport is regarded as a social instrument and a means of community development ('sport-plus').

Jikkemien Vertonghen works as a professor at the Department of Movement and Sport Sciences (Faculty of Physical Education and Physiotherapy) of the Vrije Universiteit Brussel (VUB), Belgium. In April 2011, Jikkemien received her PhD in Physical Education and Movement Sciences, in which she analyzed contextual factors in youth martial arts practice. Jikkemien's research is related to youth sports in general and martial arts practice in particular. She has a special interest in the analysis of sport programs in which sport is used as a tool to work with specific target groups towards personal, social and community development.

Kristine De Martelaer achieved her PhD in Physical Education through research on youth-centred organised swimming. Since December 2001, she has been a professor at the Faculty of Physical Education and Physiotherapy of the Vrije Universiteit Brussel (VUB). She is president of the International Centre for Ethics in Sport (ICES) and has the special Chair "Pedagogy of Physical education", embedded in the division of Education of the faculty of Social and Behavioral Sciences of Utrecht University (since 2015). She currently teaches sport history \& philosophy, didactics, PE curriculum development, and basic life support (BLS). Her research topics are within sport pedagogy: fundamental movement skills of young children, competences of PE teachers and voluntary youth coaches, didactical approaches of responsibility-based teaching, ethics in sport, water safety and basic life support (BLS). 